\title{
Agricultural Water Pricing: United States
}
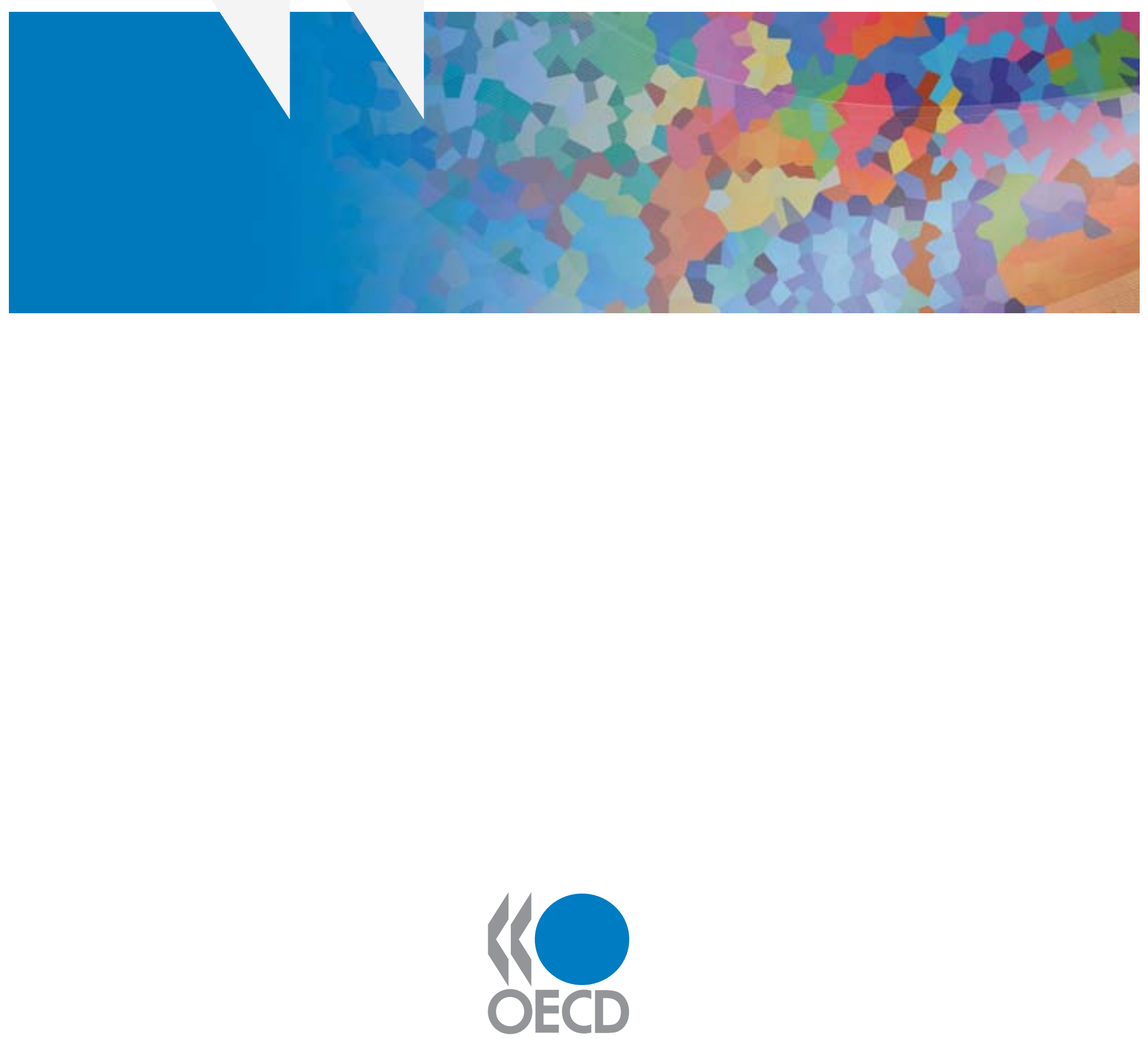


\section{ORGANISATION FOR ECONOMIC CO-OPERATION AND DEVELOPMENT}

The OECD is a unique forum where the governments of 30 democracies work together to address the economic, social and environmental challenges of globalisation. The OECD is also at the forefront of efforts to understand and to help governments respond to new developments and concerns, such as corporate governance, the information economy and the challenges of an ageing population. The Organisation provides a setting where governments can compare policy experiences, seek answers to common problems, identify good practice and work to co-ordinate domestic and international policies.

The OECD member countries are: Australia, Austria, Belgium, Canada, the Czech Republic, Denmark, Finland, France, Germany, Greece, Hungary, Iceland, Ireland, Italy, Japan, Korea, Luxembourg, Mexico, the Netherlands, New Zealand, Norway, Poland, Portugal, the Slovak Republic, Spain, Sweden, Switzerland, Turkey, the United Kingdom and the United States. The Commission of the European Communities takes part in the work of the OECD.

(C) OECD 2010 


\title{
Agricultural Water Pricing: United States
}

\author{
DENNIS WICHELNS
}

HANOVER COLLEGE, INDIANA, UNITED STATES OF AMERICA 


\begin{abstract}
Note
This document, Agricultural Water Pricing: United States, by Dennis Wichelns, of Hanover College, Indiana, is one of the background reports supporting the OECD study (2010) Sustainable Management of Water Resources in Agriculture, which is available at www.oecd.org/water.

The report was carried out under the auspices of the OECD Joint Working Party on Agriculture and the Environment of the Committee for Agriculture and the Environment Policy Committee. The report is published under the responsibility of the author and does not necessarily reflect the views of the OECD or its member countries.
\end{abstract}

The other background reports (also available at www.oecd.org/water) are:

An Economic Analysis of the Virtual Water Concept in Relation to the Agri-food Sector Dennis Wichelns, Hanover College, United States http://dx.doi.org/10.1787/786736626756

Agriculture's Role in Flood Adaptation and Mitigation - Policy Issues and Approaches Joe Morris, Tim Hess and Helena Posthumus, Cranfield University, United Kingdom http://dx.doi.org/10.1787/786804541573

Environmental Effectiveness and Economic Efficiency of Water Use in Agriculture:

The Experience of and Lessons from the Australian Water Reform Programme

Michael D. Young, University of Adelaide, Australia

http://dx.doi.org/10.1787/786732081512

Financing Water Management and Infrastructure Related to Agriculture across OECD Countries Frank A. Ward, New Mexico State University, United States

http://dx.doi.org/10.1787/786788524232

Agricultural Water Pricing: EU and Mexico

Alberto Garrido, Universidad Politécnica de Madrid; and

Javier Calatrava, Universidad Politécnica de Cartagena, Spain

http://dx.doi.org/10.1787/787000520088

Agricultural Water Pricing in Japan and Korea

James E. Nickum and Chisa Ogura, Asian Water and Resources Institute, Japan

http://dx.doi.org/10.1787/787011574235

Agricultural Water Pricing in Turkey

Erol H. Cakmak, Middle East Technical University, Turkey

http://dx.doi.org/10.1787/787034266022

Agricultural Water Pricing: Australia

Seamus Parker, Council of Mayors (South-East Queensland); and

Robert Speed, Freelance Consultant, Australia

http://dx.doi.org/10.1787/787105123122 


\section{Table of Contents}

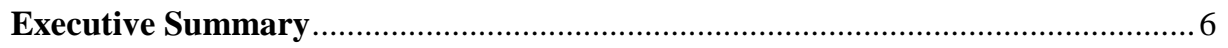

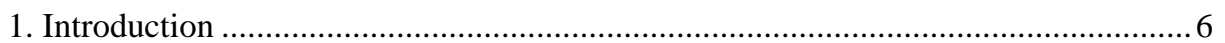

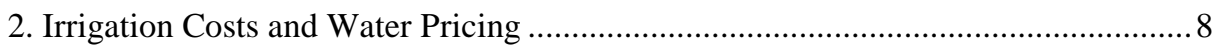

3. Country Case Study: United States................................................................. 10

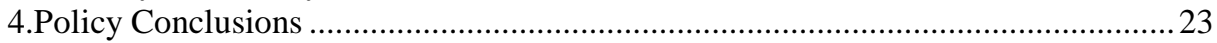

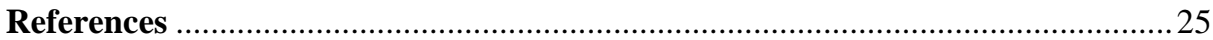




\section{Executive Summary}

Prices and costs pertaining to irrigation water in the United States vary substantially with geographic location, water sources, and institutional arrangements. There is notable variation also in irrigation strategies, and in water supplies and demands, in eastern and western regions of the United States. In western states, irrigation provides most of the crop water requirements, while in eastern areas irrigation is largely supplemental. Water laws and allocations were established long ago in the arid western states, while water policies are much less developed in the humid eastern states.

Current irrigation prices in western states reflect both the historical implications of long-term contracts for water developed by the U.S. Bureau of Reclamation and the more recent views of the U.S. Congress and several state governments regarding the need to recover larger portions of the cost of building and operating irrigation projects. Many farmers receive water also from privately formed irrigation companies that operate and maintain conveyance facilities. Full supply-cost recovery is essential for such entities, and farmers have been paying those costs for many years.

Given the variety of water rights, allocations, and contractual arrangements that characterize irrigation in the United States, there is a wide range also in the prices paid for irrigation water. Some farmers with riparian water rights or exchange agreements with the federal government receive water at very low cost (USD5 to USD10 per $1,000 \mathrm{~m}^{3}$ ), while other farmers with less favorable contracts or those who purchase water from some state-level irrigation agencies pay much higher prices (ranging from USD20 to more than USD100 per 1,000 $\mathrm{m}^{3}$ ). Farmers purchasing water in market transactions to finish an irrigation season or to ensure water supply for perennial crops might pay prices that exceed USD100 per $1,000 \mathrm{~m}^{3}$ for a portion of their irrigation supply.

The cost of irrigation water has increased substantially in a large portion of the United States that relies on groundwater from the Ogallala Aquifer. Rising energy costs and declining water levels have motivated many farmers to improve water management, in part, by replacing surface irrigation with more costly center-pivot and low-pressure sprinklers, and subsurface drip irrigation. A current estimate of the variable costs of irrigating in the region, while pumping from a depth of 61 meters, is USD772 per hectare (Seo et al., 2008).

In summary, irrigation costs and prices are rising in most regions of the United States, due to a combination of increasing scarcity, changes in public preferences regarding water allocation among competing uses, increasing budget scrutiny in the national and state legislatures, rising energy prices, and increasing awareness of climate change and the potential implications for rainfall and the availability of surface water resources. These issues likely will continue encouraging public officials to utilize water pricing and other market-based incentives to motivate further improvements in water use efficiency in agriculture and other sectors.

\section{Introduction}

\subsection{Motivation}

Public interest in the issue of irrigation water pricing has increased worldwide in recent years, with increasing awareness of water scarcity and greater appreciation of the opportunity costs of allocating water among competing uses. Many of the world's large-scale irrigation projects were constructed and placed in service in an era when water was relatively abundant or when the cost of developing water supplies in arid regions seemed a reasonable expense for expanding agricultural production and generating economic growth. Over the years, the incremental costs and benefits of irrigation have changed, as have public preferences regarding the allocation of water among agricultural, municipal, and environmental uses. With increasing scarcity, the opportunity cost of choosing one use over another increases as well.

Private and public investments in irrigation have greatly enhanced agricultural productivity in many regions, enabling the world to sustain an ever-increasing population (Carruthers et al., 1997). As the world population doubled from about 3 billion in 1961 to about 6 billion in 1996, irrigated area increased from about 139 million hectares to 263 million hectares (Howell, 2001). As a result, the irrigated area per person, worldwide, has 
remained relatively constant. Irrigated area in the United States increased until about 1980, when it reached about 20 million hectares. Average use of irrigation water, per hectare has declined in the United States, while yields have increased steadily with improvements in agricultural technology (Howell, 2001).

Some of the public investments in irrigation in the United States and other countries have involved large expenditures that governments have not fully recovered from project beneficiaries over time. The subsidies implicit in the lack of cost recovery have gained the attention of citizens and legislators concerned with public budgets, resource allocation, and the off-farm impacts of irrigation and drainage in some areas. Many observers agree that irrigation will play a major role in providing sufficient food for the world's increasing population, but many also wish to see the full costs of irrigation reflected in farm-level irrigation water prices (Merrett, 2002). Accurate prices can promote irrigation efficiency within agriculture and increase the likelihood of achieving economic efficiency across the sectors that compete for limited water resources.

Subsidies for irrigation water also are discussed in the context of international trade and natural resource management. In the trade setting, irrigation subsidies can generate a competitive advantage for farmers in one country, if farmers in another country are required to pay water charges that reflect a greater range of cost components. To date, there is no published evidence of such a competitive advantage, but the topic arises in policy discussions. From a resource management perspective, farmers will have a greater incentive to irrigate efficiently and choose higher valued cropping patterns if water charges reflect the full cost of development and the opportunity costs of using water in other sectors. However, in many areas, charging the full cost of providing irrigation water would reduce net farm income in ways that might not be desirable from a social welfare perspective.

Many authors have called for the elimination of irrigation subsidies, at times suggesting that water is a commodity and should be priced accordingly. They describe the potential gains in irrigation efficiency and the public value of communicating scarcity conditions through market-based prices. Other authors suggest that subsidies can be justified because irrigation projects provide both public and private goods, or that higher water prices will reduce agricultural net revenues without motivating notable reductions in irrigation diversions. Those authors often cite the low elasticities of demand for irrigation water observed in many settings. When demand is price inelastic, quantity demanded declines by a smaller proportion than an increase in price, such that revenues collected from water users increase substantially, with little change in the volume of irrigation water used.

The issue of irrigation water pricing arises also in discussions of sustainability. If farmers pay only for the current costs of operating and maintaining a public irrigation facility, revenues will fall short of the amount needed to rehabilitate the system and invest in new features, over time. Sustainability might also require that water prices reflect the long-term implications of irrigation, such as the potential for developing waterlogged and saline areas, and the off-farm impacts of irrigation and drainage, such as the transport of sediment and pollutants into streams and lakes. Where farmers irrigate with groundwater, the private cost of pumping might not reflect the near-term impacts on other water users or the long-term impacts of maintaining withdrawals in excess of recharge. Groundwater fees and allocation policies might be needed to motivate farmers to reduce pumping rates to levels that ensure sustainability.

Irrigation pricing is discussed also in the context of multiple interventions or distortions involving public policies. For example, some authors and legislators have expressed concern that many farmers in the western United States use federally subsidized irrigation water to produce crops for which the prices are supported by other government programs. In a sense, such farmers receive a "double subsidy" from the federal government. Some authors have described a third issue involving the off-farm impacts of irrigation and drainage in areas with saline high water tables or seleniferous soils.

Interventions and price distortions involving irrigation water and other inputs and crop prices are notable also in developing countries. Many governments restrict the prices farmers receive for their crops or maintain overvalued exchange rates that artificially reduce the prices of imports while increasing the prices of exports. Farmers receiving subsidized irrigation water in those cases might argue that they pay for the water indirectly, as such interventions reduce farm-level revenues. Many farmers and authors note also that implementing or raising irrigation prices can be challenging in situations where the revenue is placed in general fund accounts, rather than used to improve irrigation services or invest in new facilities.

Public interest in irrigation pricing has increased also in conjunction with interest in other farm inputs and cropping patterns. Farmers choose crops and input combinations based largely on relative prices, often without due consideration for the off-farm impacts of their decisions. For example, when corn and nitrogen are inexpensive, corn is an attractive production alternative, but excessive irrigation can cause nitrogen to move into 
rivers, lakes, and groundwater. Higher irrigation prices might indirectly reduce nitrogen effluent, just as higher nitrogen prices might encourage farmers to plant more soybeans than corn. The "double subsidy" issue arises in this context also, as the federally supported price of ethanol in the United States generates higher market prices for corn, thus attracting greater production. Inadequate prices for water and other inputs can increase the public costs of maintaining the ethanol program.

\subsection{Objectives}

The primary goal of this study is to describe the nature of irrigation water pricing in the United States in a manner that informs public officials considering policies that influence farm-level decisions regarding water use and other production decisions. A corollary objective is to describe the range of irrigation water prices and other farm-level costs of obtaining irrigation water in the United States. Prices and costs vary substantially throughout the country, ranging from very low in some areas at some times of the year, to quite high in other locations, particularly during periods of peak demand. Prices and costs are increasing over time in most areas, with notable implications for water use efficiency, water allocation, economic efficiency, and farm-level costs and returns.

\section{Irrigation Costs and Water Pricing}

Prices and costs pertaining to irrigation water in the United States vary substantially with geographic location, water sources, and institutional arrangements. There is notable variation also in irrigation strategies, and in water supplies and demands, in eastern and western regions of the United States. In western states, irrigation provides most of the crop water requirements, while in eastern areas irrigation is largely supplemental. Water laws and allocations were established long ago in the arid western states, given the region's climate and the tendency for water demands to exceed water supply in many areas. Water policies are much less developed in the humid eastern states, where water supplies have generally been sufficient to meet demands, except during periodic droughts. There is a much longer history of defining water rights, enforcing water allocations, and pricing irrigation water deliveries in western states.

Water policies and prices pertaining to surface water often differ from those pertaining to groundwater. Many western states regulate surface water supplies very carefully, while groundwater withdrawals are not subject to close regulation. In some areas farmers prefer to use groundwater for irrigation because the only cost of consumption is the cost of operating and maintaining irrigation wells and pumps. Some states regulate the volume of groundwater a farmer can withdraw each year, while some states do not regulate groundwater withdrawals. The cost of pumping groundwater varies among regions, according to pumping depths and energy prices.

Institutional arrangements greatly influence the prices that farmers pay for irrigation water in western states. Water prices can vary substantially within a small region if some farmers have senior or riparian water rights, while other farmers purchase water from a public or private purveyor. In some states the price gap has narrowed in recent years, as new water contracts have replaced older agreements that were crafted when water supplies were less scarce. Still, there is notable disparity in irrigation water prices and, consequently, in the ways in which irrigation water is used.

\subsection{Institutional Considerations}

Water allocation principles and the systems of water rights that have evolved over time in the United States reflect the influence of European laws, particularly in the humid eastern states, and the unique circumstances of water supplies and demands in the arid western states (Teerink, 1993a). Riparian rights work well in the eastern states, where many farmers and other water users divert water directly from adjacent streams and rivers. Riparian rights are less useful in the arid west, where substantial water demands occur on lands located far from surface water sources.

The appropriation doctrine of water rights arose to accommodate the diversion and transport of surface water for use on non-adjacent lands. Early settlers and miners in the western states formalized their appropriative water rights by posting notices of intent to divert water and registering their notices in local government offices (Teerink, 1993a). Over time, state legislation and court decisions recognized appropriative water rights and began assigning seniority to rights according to the year in which they were established. The notion of "first in time, first in right" was initially adopted by custom, and later was encoded in law (Teerink, 1993a). Due largely to their 
prevalence in the arid western states, appropriative water rights currently account for substantially more water diversions than riparian rights in the United States.

Systems of groundwater rights in the United States are more complex than those involving surface water. They generally involve one of four doctrines (Teerink, 1993a): 1) absolute ownership, 2) rule of reasonableness, 3) correlative rights, and 4) prior appropriation. Absolute ownership is similar to the notion of a riparian right in the case of surface water. A landowner may extract and utilize groundwater, without restriction and without concern for other landowners pumping from the same aquifer.

The rule of reasonableness doctrine requires overlying landowners to use groundwater wisely. The doctrine can restrict landowners from applying groundwater on non-overlying lands if there are negative impacts to other landowners pumping from the same aquifer. Correlative rights are more restrictive, as they require landowners to share the impacts of water scarcity. Limited water supplies are allocated among landowners accord to the amount of land they own above the aquifer. Prior appropriation considers groundwater to be a resource of the state that is subject to development and use, as in the case of appropriative rights applied to surface water (Teerink, 1993a).

Much of the irrigation water in the western United States is developed and delivered by state or federal agencies, such as the U.S. Bureau of Reclamation and state-level departments of water resources. The state and federal agencies generally do not work directly with individual farmers. Rather, they form contractual relationships with irrigation districts (water user associations) that represent groups of farmers (Burt, 2007). The irrigation districts collect fees from their members, in return for providing water delivery services. The districts use those revenues to pay for their costs of capital, operations, and maintenance, and for paying the state or federal agency for the district's water supply.

The supplies of irrigation water available to districts are determined, in part, by historical water rights arrangements and by the contractual relationships they have formed with state and federal agencies. Water rights are determined, issued, and managed by state governments, rather than the federal government. In most western states, water rights are defined in conjunction with land ownership (Green and Hamilton, 2000). Hence, land values reflect the value of water rights and as land is purchased or sold, so too are the water rights.

Conflicts involving water rights are resolved in state courts if they cannot be resolved within state water management agencies. States also develop rules and regulations regarding the sale or lease of water rights. Some states are more advanced than others in promoting water markets, and some states actively manage groundwater, while other states allow landowners to use groundwater with little regulation. Some states have assisted farmers and others in obtaining water during sustained droughts by creating centralized "water banks" in which buyers and sellers can exchange information and conduct transactions (Green and Hamilton, 2000).

The variation in state policies and in the sources, supplies, and demands for irrigation water generates substantial variation in water prices and availability. In some states, particularly in the western region, historical water rights also play an important role in determining the price and availability of water at the farm level. In some areas, farmers with senior water rights or riparian water rights obtain irrigation water at very low cost and with good reliability. Many farmers with less well-established water rights, and those who purchase water from public or private purveyors, face higher prices and less reliable supplies.

In some areas, institutional innovations, such as water leasing and water transfers have reduced the effective disparity in farm-level water availability in some years. Water markets include cases in which farmers voluntarily lease or sell a portion of their surface water allocation and cases in which some farmers in a region withdraw and sell groundwater to other farmers or to a surface water purveyor. Water marketing generally improves the efficiency of water use in a region, as water is moved from relatively low valued uses to higher valued uses. The incremental farm-level price of irrigation water, when determined in local water market transactions, will vary with water demand and supply conditions.

\subsection{Cost Components}

Merrett (2002) describes five categories of farm-level water costs that include variations of direct and indirect prices and fees (Table 1). All of these categories, with the possible exception of "zero cost" can be found in some region of the United States. Farmers using groundwater or diverting directly from a river according to a riparian water right likely must pay only their "own-supply costs." Those costs will rise and fall with changes in energy prices and changes in groundwater levels or flow rates in rivers. Many farmers pay volumetric water charges, particularly in the western United States, where advanced methods of measuring farm-level water deliveries have 
been in place for many years. "Indirect fees" and "revenue-only" fees are found in some of the smaller canal companies that deliver water to their members on a per-hectare or per-time unit basis.

Molle and Berkoff (2008) describe several goals of irrigation pricing, within the context of policy tools. In particular, water pricing can serve as a financial policy tool by ensuring that some portion of the costs of constructing and operating an irrigation project are recovered. Water pricing also can serve as an economic policy tool by encouraging efficient use of water and motivating farmers and others to employ water in appropriately valued uses. Lacking water prices, there may be little incentive to improve water management or to move water from low-valued to high-valued uses. Water pricing can serve as an environmental policy tool when improvements are needed to reduce the off-farm impacts of irrigation and drainage or to slow the rate of depletion of nonrenewable groundwater.

Table 1.

Farm-level cost categories for irrigation water deliveries

\begin{tabular}{|c|c|c|c|}
\hline Category & Units & $\begin{array}{l}\text { Can Influence } \\
\text { Water Demand }\end{array}$ & $\begin{array}{c}\text { Contributes to } \\
\text { Agency Revenue }\end{array}$ \\
\hline Zero charge & None & & \\
\hline Own-supply cost & $\begin{array}{l}\text { Euros per } \mathrm{m}^{3} \\
\text { plus own labor per } \mathrm{m}^{3}\end{array}$ & Yes & \\
\hline Volumetric price & Euros per $\mathrm{m}^{3}$ & Yes & Yes \\
\hline Indirect fee & $\begin{array}{l}\text { Such as Euros per ha of a } \\
\text { specified crop, or Euros per } \\
\text { time period allocated }\end{array}$ & Yes & Yes \\
\hline Revenue-only fee & Such as Euros per hectare & & Yes \\
\hline
\end{tabular}

The policy tool framework is helpful in understanding the complexity of irrigation water prices observed in many areas of the United States. State and federal water agencies and the irrigation districts with which they enter contractual relationships often establish prices that include one or more components reflecting policy goals that align somewhat with the Molle and Berkoff (2008) policy tools. For example, irrigation water prices in the federal Central Valley Project in California include cost recovery charges (financial policy goal) and an environmental restoration charge (environmental policy goal). Water prices in California's State Water Project include charges for repaying all construction costs, with interest (financial policy goal), thus ensuring that decisions regarding water use and allocation reflect the full cost of developing and delivering the state's limited water supply (economic policy goal).

\section{Country Case Study: United States}

\subsection{Irrigation Areas and Water Sources}

The use and pricing of irrigation water vary considerably across productive regions in the United States. Most irrigation occurs in the arid western states, where rainfall is insufficient for producing most crops (USDA, 2006). Of the estimated 197 billion $\mathrm{m}^{3}$ of water withdrawn for agriculture in 2000,168 billion $\mathrm{m}^{3}(86 \%)$ were withdrawn in the 19 western states that comprise the Pacific, Mountain, and Plains regions (Table 2). Agriculture is a major user of water withdrawals in those states, accounting for $80 \%$ of total withdrawals in the Pacific and Mountain 
regions, respectively, and $49 \%$ of withdrawals in the Plains states. Nearly all of the agricultural withdrawals are used for irrigation, with only a small amount used for livestock and aquaculture. Surface water is the major source of agricultural water in the Pacific and Mountain regions, while groundwater is the major source in the Plains region.

The South, North Central, and Eastern regions of the United States generally are more humid than the western regions, and less water is required for irrigation. Agricultural withdrawals account for $30 \%$ of total withdrawals in the South and just 3\% of withdrawals in the North Central and East (Table 2). As in western states, most agricultural withdrawals are used for irrigation, although $19 \%$ of withdrawals are use for livestock and aquaculture in the North Central and East. Groundwater is the source for almost two-thirds of agricultural withdrawals in these regions. Nationwide, surface water was the source for $59 \%$ of agricultural withdrawals in 2000, while groundwater was the source for $41 \%$ of withdrawals.

Table 2.

Agricultural water withdrawals, by region and total, United States, 2000

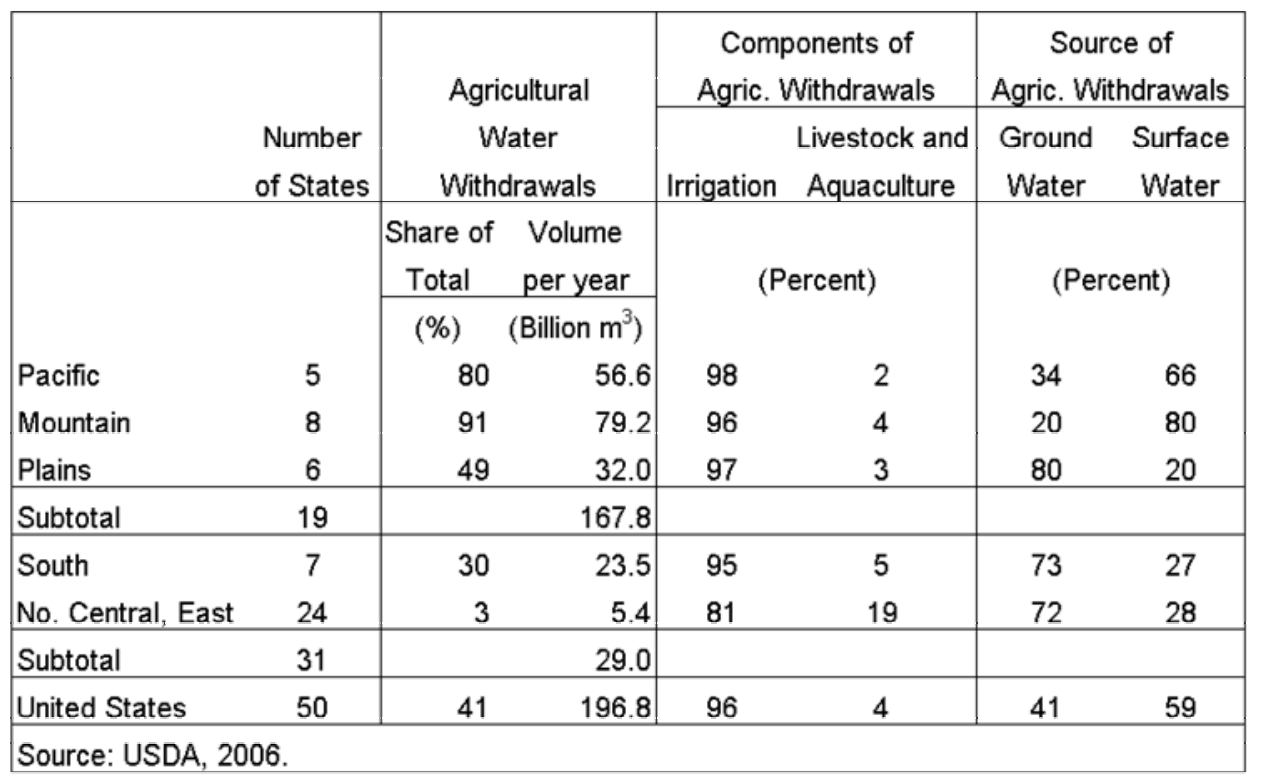

Leading irrigation states in the Pacific, Mountain, and Plains regions include Arizona, California, Colorado, Idaho, Montana, and Texas. Together, these states accounted for about 112 billion $\mathrm{m}^{3}$ of water withdrawals for irrigation in 1990 (Table 3). The proportions of water withdrawn from surface sources and groundwater, and from public and private sources, vary substantially among these states. The U.S. Bureau of Reclamation, which provides water service in 17 western states, delivers notable portions of the surface water withdrawn for irrigation in California, Idaho, and Arizona. Private suppliers furnish notable portions in all states, but particularly in the Rocky Mountain states of Colorado and Montana. Texas obtains two-thirds of its irrigation withdrawals from groundwater, while groundwater accounts for $35 \%$ to $39 \%$ of irrigation withdrawals in California, Idaho, and Arizona. Nationwide, surface water accounts for $63 \%$ of irrigation withdrawals, while groundwater accounts for $37 \%$. 
Table 3.

Irrigation withdrawals, by source, for selected western states, 1990

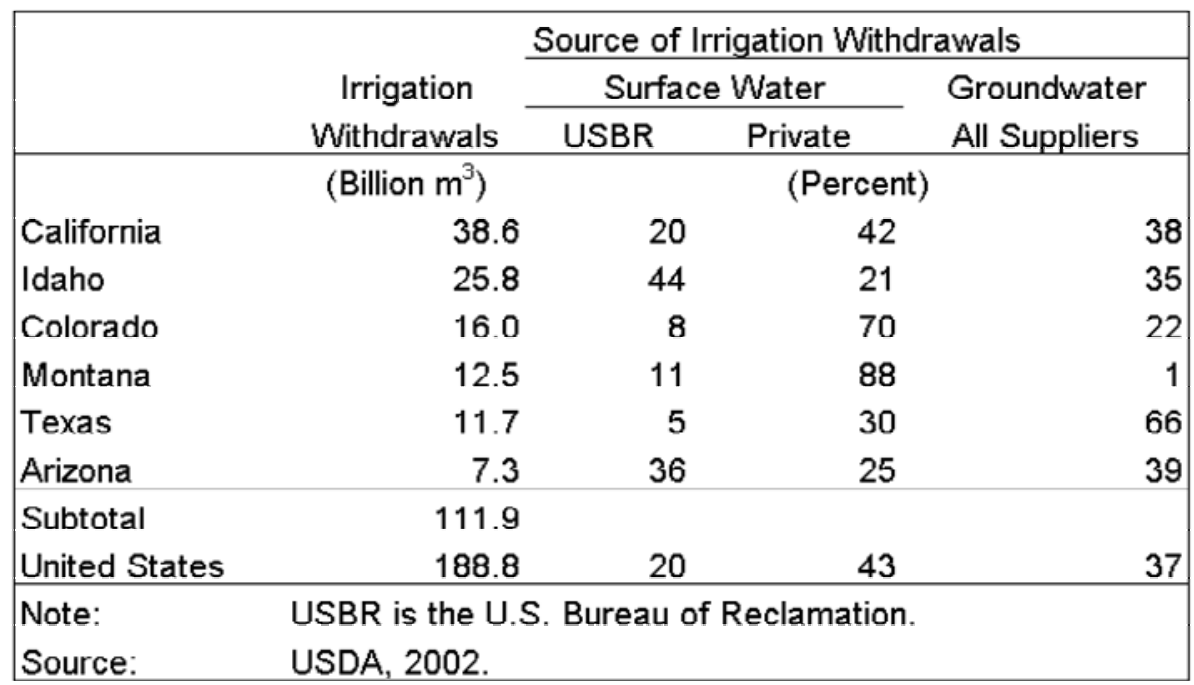

Table 4

Irrigation withdrawals, by source, for selected eastern states, 1990

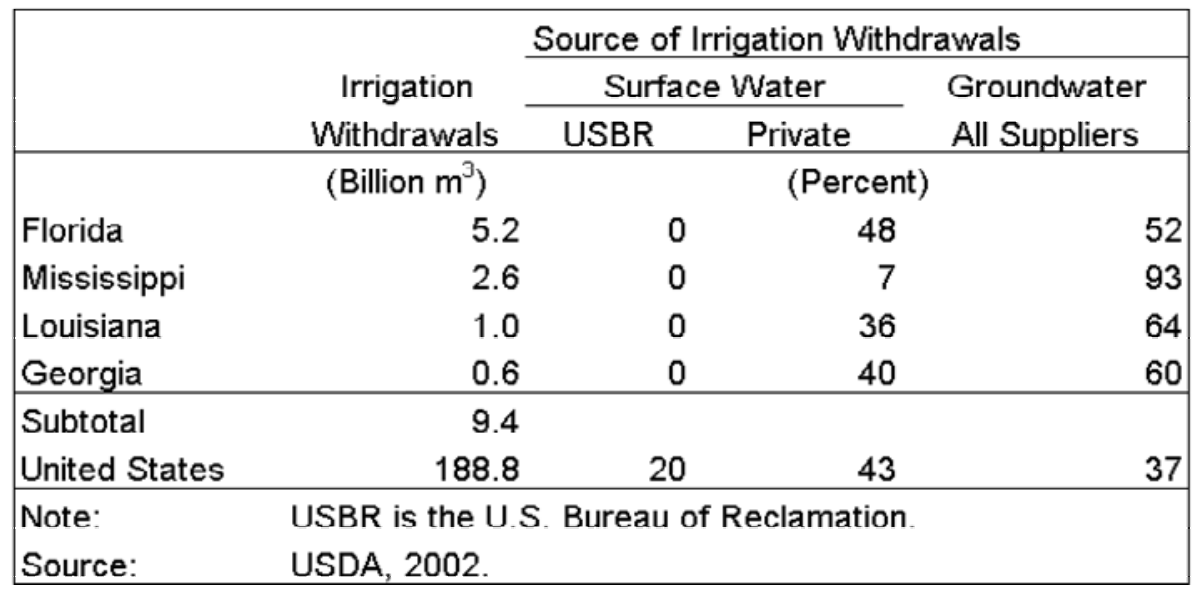

As noted above, irrigation withdrawals are much smaller in the humid, eastern region of the United States. Fewer than 10 billion $\mathrm{m}^{3}$ of water were withdrawn for irrigation in the four southeastern states of Florida, Mississippi, Louisiana, and Georgia in 1990 (Table 4). Groundwater accounted for nearly all of the irrigation withdrawals in Mississippi, and more than half the withdrawals in Florida, Louisiana, and Georgia. Although the scale of irrigation generally is much smaller in the north central, eastern, and southern states, public issues regarding water rights, allocation, and pricing are gaining importance in those regions as the demand for water increases due to population pressure, expansion of economic activity, and greater demand for environmental amenities derived from water resources (Elfner and McDowell, 2004; Petrie and Taylor, 2007).

Irrigation withdrawals in the 19 western states were equivalent to an average of almost $9,100 \mathrm{~m}^{3}$ per hectare in 1998, while withdrawals in the 31 eastern states were equivalent to an average of $4,000 \mathrm{~m}^{3}$ per hectare (Gollehon and Quinby, 2000). The average application of irrigation water in western states was about $6,100 \mathrm{~m}^{3}$ per hectare in 1998 , as about $3,000 \mathrm{~m}^{3}$ per hectare were lost in conveyance. Average application rates included $4,000 \mathrm{~m}^{3}$ per hectare for center-pivot sprinklers, $5,200 \mathrm{~m}^{3}$ per hectare for other sprinklers, $6,400 \mathrm{~m}^{3}$ per hectare for microirrigation systems, and 7,300 $\mathrm{m}^{3}$ per hectare for all gravity systems (Gollehon and Quinby, 2000). 


\subsection{Water Prices, Costs, and Policies}

The United States Department of Agriculture (USDA) conducts nationwide farm surveys periodically to assess cropping patterns, production methods, and the costs and returns of both irrigated and non-irrigated agriculture. The USDA's 2003 Farm and Ranch Irrigation Survey (FRIS) provides a relatively recent overview of irrigation water sources and costs, and irrigation methods used by farmers throughout the country. Much of the discussion in this section relies on Chapter 2.1 of the 2006 edition of the Agricultural Resources and Environmental Indicators report prepared by USDA (2006), authored by Noel Gollehon and William Quinby.

The cost per $\mathrm{m}^{3}$ of pumping groundwater depends primarily on pumping depth, energy source, and the current price of energy. The cost per hectare for groundwater varies also with the volume of groundwater used during the season. These variables give rise to substantial variation in both the cost per $\mathrm{m}^{3}$ and the cost per hectare in different regions of the United States. As noted by Gollehon and Quinby (2006), nearly half of the farms in the country, representing more than 13 million hectares, use some groundwater. The cost per hectare of pumping groundwater ranges from USD17 per hectare in Maryland to USD435 per hectare in Hawaii. Maryland is a humid, eastern state with a short growing season in which rainfall often is sufficient to produce most crops. Farmers in Hawaii irrigate longer season crops and likely have higher energy costs than farmers in many other states.

Other examples of per-hectare pumping costs include USD195 per hectare in California and USD227 per hectare in Arizona. Irrigation often is needed for $100 \%$ of crop water requirements in these arid, southwestern states. Assuming an average irrigation delivery of $10,000 \mathrm{~m}^{3}$ of water per hectare, these costs would be equivalent to USD19 per $1,000 \mathrm{~m}^{3}$ in California and USD23 per $1,000 \mathrm{~m}^{3}$ in Arizona. The national average cost of pumping groundwater, as reported in the 2003 FRIS, was almost USD100 per hectare (Gollehon and Quinby, 2006).

Similar variation is observed in the 2003 FRIS for the costs of lifting and delivering surface water, and pressurizing surface irrigation systems. Surface water was used to irrigate more than 4.25 million hectares in 2003, and the average cost ranged from USD25 per hectare in Missouri to USD203 per hectare in Massachusetts (Gollehon and Quinby, 2006). Examples within this range include USD89 per hectare in California and USD101 per hectare in Washington. Surface water costs generally are lower than groundwater costs, as less vertical lift is required when diverting water from a lake or river (Gollehon and Quinby, 2006).

Farmers purchasing water from an off-farm source applied that water on almost 5.7 million hectares in 2003. The range of costs in this category is from USD12 per hectare in Minnesota to USD213 per hectare in California, with a national average cost of USD104 per hectare (Gollehon and Quinby, 2006). Other examples include USD114 per hectare in Washington and USD178 per hectare in Arizona. Lacking information regarding how much water is purchased, it is not possible to estimate the average cost per $\mathrm{m}^{3}$ of water in this category.

\subsection{Water Prices and Repayment Policies in the American West}

About $85 \%$ of agricultural water withdrawals occur in the 19 western states included in the Pacific, Mountain, and Plains regions described above. Within those states, water is withdrawn and delivered for irrigation by both private and public purveyors. Many landowners withdraw groundwater from private wells and irrigate without restrictions on pumping rates or volumes. Some states have groundwater management programs in which withdrawals are limited and new wells cannot be constructed without permits, while other states do not impose restrictions. Many private and public irrigation entities also withdraw groundwater, often for supplementing surface water supplies.

Many privately formed canal companies and water districts deliver surface water to groups of farmers who essentially own the companies. Boards of directors comprised of landowners in the district hire managers who are responsible for hiring staff members to operate and maintain canals, and deliver water to farmers at reasonable cost and with good reliability. These companies and districts must charge prices for water and service that enable them to recover their costs of securing water, operating, maintaining, and repairing their systems, and also generate capital replacement and reserve accounts. In this sense, farmers receiving water from privately formed canal companies and water districts pay the full supply-cost of water service, although the cost is not always imposed as a volumetric charge. As the costs of operating and maintaining these canal companies and water districts have increased over time, so too have the prices farmers must pay for irrigation water (Wilkins-Wells $e t$ al., 1999). 
The largest public purveyor of irrigation water in the American West is the U.S. Bureau of Reclamation (USBR), which develops and delivers water in wholesale fashion to locally organized irrigation districts that provide water service to farmers. Since 1902, USBR has constructed more than 130 projects that provide irrigation water for about $25 \%$ of irrigated area in the American West, at a cumulative development cost of about USD21.8 billion (Gollehon and Quinby, 2006). Many USBR projects provide multiple benefits that include hydropower development, flood control, and recreation. The repayment obligation for the construction costs of USBR projects generally is allocated among beneficiaries according to the proportion of benefits received from the projects (GAO, 1996).

The United States Congress directed the Bureau of Reclamation to allocate the construction costs of irrigation projects to farmers, and to allow repayment without interest. The Congress instructed the Bureau also to determine repayment schedules based on farmers' ability to pay. In sum, the federal law that created the Bureau of Reclamation allows farmers to receive three types of financial subsidies (GAO, 1996):

1. Interest-free repayment of a project's construction costs. The value of the foregone interest is essentially a subsidy from the federal government.

2. Reduced repayment obligation, based on ability to pay. The federal government can shift some of the costs allocated to irrigation to other project beneficiaries when repayment of some or all of those costs is determined to be greater than farmers' ability to pay.

3. Reduced repayment obligation, due to special circumstances. The federal government can cancel some or all of farmers' repayment obligation through specific laws that apply to special circumstances, such as economic hardship, settlement of Indian water rights claims, unproductive lands, or drought.

Over time, the project-level and cumulative values of such subsidies have been substantial. One example is the USBR's Tualatin irrigation project in Oregon, for which the total construction cost was USD58.7 million. When water became available to farmers in 1976, analysts determined that farmers could repay only USD5.9 million of the USD31.5 million in construction costs allocated to irrigation (GAO, 1996). Repayment of the remaining USD25.6 million ( $81 \%$ of the allocated costs) was shifted to other beneficiaries; specifically the commercial users of electricity generated by the project.

Federal reclamation law enables irrigators to repay their allocated costs without interest over long repayment periods. In the case of the Tualatin project, irrigators were expected to repay their costs over 64 years. The present value of their expected payments during that time was USD0.9 million, or about 3\% of the USD31.5 million in construction costs allocated to irrigation. Hence one estimate of the federal subsidy to irrigators obtaining water from the Tualatin project is USD30.6 million, or 97\% of the allocated construction costs (GAO, 1996).

Reclamation law distinguishes between reimbursable and non-reimbursable costs. In general, reimbursable costs are those that generate measurable benefits for identifiable users of a project. These include costs allocated to irrigation, municipal and industrial water supply, and power (GAO, 1996). Non-reimbursable costs generally are those that generate public goods and are, therefore, paid by the federal government. Examples include the costs of providing navigation, flood control, recreation, and amenity benefits, such as the provision of fish and wildlife habitat.

The reimbursable portion of the USD21.8 billion cumulative investment cost in 133 USBR projects constructed through 1994 is USD16.9 billion (GAO, 1996). Of that amount, USD7.1 billion has been allocated to irrigators. However, that amount has been adjusted due to ability-to-pay considerations and reductions for special circumstances, resulting in a net repayment obligation from irrigators of USD3.4 billion, or $48 \%$ of their repayment obligation. The Reclamation Project Act of 1939 enabled USBR to reduce repayment obligations based on financial analysis of typical crop production budgets in a project service area (Moore, 1999).

The notion of interest-free repayment of the construction costs for irrigation projects arose from the original intent of the Reclamation Act of 1902, in which the U.S. Bureau of Reclamation was established. At that time, the United States was interested primarily in extending economic development across the western states, and irrigation was seen as a key input to that objective. Hence, the federal government was keen to receive repayment of the principal it invested in irrigation projects, but was willing to forego any interest payments from farmers (Rezendes, 1997). The Reclamation Act of 1902 included a repayment period of ten years. Later amendments to that Act extended the repayment period to 40 years, while adding a development period of 10 years, and allowing reductions in the repayment obligation due to special circumstances, such as unproductive lands in some project areas. 
The issue of providing interest-free repayment of capital costs to irrigators gained substantial public attention in the 1980s and 1990s, due partially to the increasing competition for water resources in the western United States, the environmental implications of large-scale irrigation projects, and efforts to reduce federal government expenditures (GAO, 1991, 1994). In addition, many of the long-term water contracts with irrigation districts were due to expire in the 1990s, creating the opportunity to revise contract language during the renewal process. Many observers of federal irrigation policy called for higher water prices in the new contracts to motivate improvements in water management and increase the pace at which farmers repay their capital cost obligations.

The Central Valley Project (CVP) in California provides a helpful example of the contract renewal process and the implications for irrigation prices. The CVP, which is the largest of the Bureau of Reclamation's water resource projects, was first authorized for construction in 1935 and the first feature was constructed in 1942 (GAO, 1985). Today, the Bureau delivers up to 7.4 billion $\mathrm{m}^{3}$ each year to irrigators and other customers in the Sacramento Valley in northern California and the San Joaquin Valley in central California (GAO, 1994). About $85 \%$ of the CVP's water supply is used for irrigation, while $15 \%$ is delivered to municipal and industrial users (GAO, 1991). Major crops in the Sacramento Valley include rice, tree fruits and nuts, and alfalfa hay, while major crops in the San Joaquin Valley include cotton, grains, melons, tree fruits and nuts, vegetables, and alfalfa hay.

Irrigation districts in the Central Valley Project originally signed 40-year contracts that reflected a fixed charge or water delivery and long-term repayment of reimbursable costs without interest. The fixed charge for water delivery did not increase with rising operation and maintenance costs, over time. Hence, federal revenues from irrigation districts were smaller then the costs of operating and maintaining the Central Valley Project. The United States Congress passed the Reclamation Reform Act of 1982, which required the price of irrigation water in all new contracts to fully cover operation and maintenance costs (GAO, 1991). In addition, a 1986 statutory requirement empowered the Secretary of Interior to adjust water prices if the rates were considered too low to allow full recovery of the appropriate share of the project's capital repayment obligation by 2030. By 1990, districts in the CVP had repaid only USD10 million of a repayment obligation exceeding USD1 billion (GAO, 1991).

Congress passed the CVP Improvement Act (CVPIA) in 1992, seeking to motivate further improvements in water management, raise additional revenue, and re-allocate a portion of the CVP's agricultural water supply to environmental uses. Key provisions of the CPVIA include: 1) establishment of an environmental restoration fund for mitigating previous harm from irrigation projects in the Valley, 2) legal support for water transfers within agriculture and to other users, and 3) a requirement that the Bureau of Reclamation implement an increasing block-rate pricing structure in its sale of water to irrigation districts (Loomis, 1994; Weinberg, 1997; Fischhendler and Zilberman, 2005). Revenues obtained from water sales in the highest price block would be placed in the restoration fund, and the Secretary of Interior was given authority to assess a new fee of up to USD5 per 1,000 $\mathrm{m}^{3}$ of irrigation water, if needed, to generate sufficient revenue for the fund (GAO, 1994).

Taken together, provisions in the Reclamation Act of 1982, the 1986 statutory requirement, and the 1992 Central Valley Project Improvement Act have generated notable increases in irrigation prices in California's Central Valley. The variation in prices paid by farmers also has increased due to the creation of new categories of water rates. There are three federal rates that apply in conjunction with the increasing block-rate pricing structure imposed by the CVPIA of 1992. The three federal rates are the following (GAO, 1994):

1. Fixed contract rates were established in the original CVP irrigation contracts, and were to remain fixed for the 40-year term of the contracts. These rates reflect two components: 1) repayment of the capital cost of CVP facilities, without interest, and 2) the annual operation and maintenance costs.

2. Cost of service rates become the contract rates for irrigation districts after they renew their contracts with the Bureau of Reclamation. The rates include: 1) annual operation and maintenance costs, 2) repayment of capital costs, without interest, at a rate that will complete capital cost repayment by 2030, and 3) a charge reflecting operation and maintenance deficits accruing since October 1, 1985, with interest.

3. Full-cost rates were established by amendments to reclamation law in the Reclamation Reform Act of 1982. These rates include: 1) repayment of operation and maintenance costs, and 2) the federal government's capital costs allocated to irrigation, and 3) un-reimbursed operation and maintenance expenses, with interest. 
The original reclamation law limited the delivery of federally subsidized irrigation water to 65 owned hectares. The Reclamation Act of 1982 increased the area limitation to 390 hectares of owned or leased land. Farmers irrigating land in excess of the 390-hectare limitation must pay the full-cost rate for water delivered to those lands (GAO, 1994).

In addition to federal water rates, farmers also must pay service and distribution charges imposed by their irrigation districts. Those rates generally are designed to recover the capital costs of district facilities and the annual costs of operation, maintenance, and repairs. District charges vary considerably with differences in both the fixed and variable costs of providing irrigation service. The combination of differences in federal water rates and district charges generates substantial variation in the prices paid by farmers for irrigation water in California's Central Valley. Examples of prices paid by farmers in 1992 in three of the largest districts in the Valley are shown in Table 5.

Table 5

Examples of Irrigation Water Prices in California's Central Valley Project in 1992, in dollars per $1,000 \mathrm{~m}^{3}$

\begin{tabular}{|lrrrcc|}
\hline & $\begin{array}{c}\text { Fixed } \\
\text { Contract } \\
\text { Rate }\end{array}$ & $\begin{array}{c}\text { Cost of } \\
\text { Service } \\
\text { Rate }\end{array}$ & $\begin{array}{c}\text { CVP } \\
\text { Full Cost } \\
\text { Rate }\end{array}$ & $\begin{array}{c}\text { District } \\
\text { Distribution } \\
\text { Charges }\end{array}$ & $\begin{array}{c}\text { Range of } \\
\text { Farmers' } \\
\text { Water Rates }\end{array}$ \\
\hline Westlands & 6.48 & 16.31 & 37.11 & 11.73 & 18.22 to 48.84 \\
Arvin-Edison & 2.84 & 15.48 & 26.84 & 35.25 to 75.77 & 38.09 to 102.61 \\
Glenn-Colusa & 1.62 & 5.45 & 9.32 & 4.19 & 5.81 to 13.51 \\
\hline $\begin{array}{l}\text { Notes: } \\
\text { The prices for Glenn-Colusa reflect those for CVP water only. Farmers in this }\end{array}$ \\
district receive water also pertaining to water rights that existed before the CVP \\
was constructed. \\
The Glenn-Colusa Irrigation District charges farmers by land area, rather than per \\
unit of water delivered. The distribution charges in this table are based on a \\
delivery estimate of 15,600 ${ }^{3}$ of water per hectare, the volume required to grow rice. \\
Source: This is Table 1.1 in GAO (1994).
\end{tabular}

Water rates are lowest in the Glenn-Colusa Irrigation District (GCID) due largely to its location in the Sacramento Valley, not far from Lake Shasta, where the Bureau or Reclamation collects and stores water for delivery to CVP customers. Both the cost-of-service rate and the full-cost rate are notably lower for GCID than for Westlands or Arvin-Edison, which are located in the San Joaquin Valley, much further from Lake Shasta. District distribution charges also are notably lower in GCID. Following contract renewal, the fixed cost-of-service rates have replaced the fixed contract rates, such that all farmers now pay higher water prices that include charges for both the annual operation and maintenance costs and a portion of the capital repayment cost. Farmers irrigating land in excess of the 390-hectare limitation will pay the highest price for irrigation water, ranging from USD13.51 per $1,000 \mathrm{~m}^{3}$ in Glenn-Colusa to USD48.84 per $1,000 \mathrm{~m}^{3}$ in Westlands to USD102.61 per $1,000 \mathrm{~m}^{3}$ in ArvinEdison (Table 5).

The increasing block-rate pricing requirement of the CVPIA of 1992 adds further variation in the range of water prices observed in the Central Valley, although the requirement applies to water sales from the USBR to districts, and not from districts to farmers. The Bureau is required to charge the cost-of-service rate for the first $80 \%$ of the water it delivers within each district's contract (GAO, 1994). The next 10\% of water delivered must be priced at a rate halfway between the cost-of-service rate and the full-cost rate. The final $10 \%$ of water delivered must be priced at the full-cost rate, which includes both capital repayment and interest on the capital costs (GAO, 1994). One goal of requiring this increasing block-rate structure is to generate up to USD50 million in additional revenue each year to pay for investments in fish and wildlife resources in the Central Valley.

Water prices vary also in the Central Valley among districts and farmers using water from other sources than the Central Valley Project. Many farmers obtain water the State Water Project or from the federal government through exchange agreements involving water rights on the San Joaquin River. Examples of the large range in 
water prices are shown in Table 6. The Central California Irrigation District exchanged its right to divert San Joaquin River water for deliveries by the federal government from Lake Shasta. The District receives that water from the federal government at no charge, but it must recover the costs of providing water service from its farmers. The average price charged to farmers in 1992 was USD6.78 per 1,000 $\mathrm{m}^{3}$ (Table 6). Modesto Irrigation District also has a low cost of providing water service, made possible by close proximity to a non-federal dam and reservoir.

Table 6.

Examples of Irrigation Water Prices in California Districts Not

Receiving CVP Water in 1992, in dollars per $1,000 \mathrm{~m}^{3}$

\begin{tabular}{|c|c|c|}
\hline District & $\begin{array}{l}\text { Farm-Level } \\
\text { Water Price }\end{array}$ & Source of Water \\
\hline Central California Irrigation District & 6.78 & Exchange contract \\
\hline Modesto Irrigation District & 3.35 & $\begin{array}{l}\text { Don Pedro Reservoir } \\
\text { (Non-federal facility) }\end{array}$ \\
\hline Alta Irrigation District & 15.79 & $\begin{array}{l}\text { Kings River via Pine Flat Dam } \\
\text { (Corps of Engineers Dam) }\end{array}$ \\
\hline Wheeler-Ridge Maricopa & 81.04 to 162.07 & State Water Project \\
\hline
\end{tabular}

The highest cost range appearing in Table 6 is for the Wheeler-Ridge Maricopa Water District, which receives irrigation water through a contract with the State Water Project. California requires contractors to pay the full cost of water service, including repayment for the capital costs of construction. Hence, the water prices charged to State Water Project contractors generally are substantially higher than prices charged to districts receiving water from the Central Valley Project.

Current irrigation water prices in the Westlands Water District include three components: 1) The prices charge to districts receiving water from the Central Valley Project water rate paid to the U.S. Bureau of Reclamation, 2) A charge for operating and maintaining the San Luis \& Delta-Mendota Water Authority, a regional water purveyor, and 3) A charge for operating and maintaining the Westlands Water District distribution system. The current USBR rate for irrigation water applied on the first 390 hectares is USD35.49 per $1,000 \mathrm{~m}^{3}$, which includes USD7.12 per $1,000 \mathrm{~m}^{3}$ for environmental restoration (Table 7). The USBR charge for water applied on land in excess of 390 hectares is either USD51.98 per $1,000 \mathrm{~m}^{3}$ or USD63.20 per $1,000 \mathrm{~m}^{3}$, depending on which version of the law is applicable. The Regional Water Authority applies a charge of USD23.64 per 1,000 $\mathrm{m}^{3}$ for delivering water through its canal system, regardless of which lands are irrigated. The District also charges one volumetric rate of USD18.44 per $1,000 \mathrm{~m}^{3}$.

The Westlands Water District recovers its fixed cost of operations through land-based charges that vary according to location in the District. Farmers in Area 1 of the District pay an annual assessment of USD43.07 per hectare, while farmers in Area 2 pay an annual assessment of USD72.05 per hectare (WWD, 2008). Area 2 was added to the District after its original incorporation and is located at a slightly higher elevation than Area 1. Additional infrastructure is required to facilitate water delivery to lands in Area 2. In summary, a typical farmer irrigating fewer than 390 hectares in Area 1 of Westlands will pay USD43.07 per hectare plus USD77.56 per $1,000 \mathrm{~m}^{3}$ of irrigation water. A typical farmer in Area 2 irrigating more than 390 hectares would pay USD72.05 per hectare, plus either USD 94.05 or USD105.28 per $1,000 \mathrm{~m}^{3}$ for the water delivered to those excess lands.

\subsection{The California State Water Project}

A guiding principle in the design and operation of the State Water Project (SWP) in California is that the prices of water and power made available by the Project must return to the state all of its initial investment, plus interest, and the annual costs of operation and maintenance (Teerink, 1993b). This policy of recovering the full supply-costs of water development and delivery is maintained in all years, even when the volume of water 
available is less than the sum of all contract volumes. In such years, SWP contractors are required to pay all of their fixed cost obligations, even if they receive little or no water from the Project. Only the variable costs of water service are reduced in years with water supply reductions. In 1991, following several dry years, agricultural water districts in the SWP received no water deliveries from the Project, but they had a fixed cost repayment obligation of about USD60 million (Teerink, 1993b).

Table 7.

Westlands Water District 2008-09 Water Rates and Charges

\begin{tabular}{|c|c|c|c|c|}
\hline \multicolumn{2}{|l|}{ Item } & $\begin{array}{l}\text { Cost of } \\
\text { Service }\end{array}$ & $\begin{array}{l}\text { New Law } \\
\text { Full Cost }\end{array}$ & $\begin{array}{l}\text { Old Law } \\
\text { Full Cost }\end{array}$ \\
\hline & & & / $1,000 \mathrm{~m}^{3}$ & \\
\hline \multicolumn{5}{|c|}{ U.S. Bureau of Reclamation } \\
\hline & Water Rates & 28.31 & 44.80 & 56.02 \\
\hline & Restoration Fund & 7.12 & 7.12 & 7.12 \\
\hline & Special Assessment & 0.06 & 0.06 & 0.06 \\
\hline & Subtotal & 35.49 & 51.98 & 63.20 \\
\hline \multicolumn{5}{|c|}{ Regional Water Authority } \\
\hline & Operation and Maintenance & 23.64 & 23.64 & 23.64 \\
\hline \multicolumn{5}{|c|}{ Westlands Water District } \\
\hline & Operation and Maintenance & 24.29 & 24.29 & 24.29 \\
\hline & Adjustments & -5.85 & -5.85 & -5.85 \\
\hline & Subtotal & 18.44 & 18.44 & 18.44 \\
\hline Agricultu & ural Water Rate & 77.56 & 94.05 & 105.28 \\
\hline Notes: & \multicolumn{4}{|c|}{$\begin{array}{l}\text { The USBR rates pertain to a } 64 \% \text { CVP water supply. } \\
\text { The Regional Water Authority and WWD rates pertain to a } \\
\text { water use estimate of } 40 \% \text { and a } 40 \% \text { CVP supply. }\end{array}$} \\
\hline Source: & \multicolumn{4}{|c|}{$\begin{array}{l}\text { Westlands Water District Website: } \\
\text { http://wnw.westlandswater.org }\end{array}$} \\
\hline
\end{tabular}

The full supply-cost pricing policy of the State Water Project has limited the extent of agricultural participation in the project. About one-third of the SWP supply is allocated to irrigation, while municipal and industrial customers account for about two-thirds of the supply (Teerink, 1993b). The annual water entitlements and the estimated unit water charges for 2006 are shown in Table 8. The charges vary with the amount of conveyance and pumping required to deliver water to each service area. No conveyance facilities are involved in the Feather River service area and no pumping is required. Hence, the contracting districts in that area are charged only for capital repayment and operations, maintenance, and rehabilitation. Substantial conveyance and pumping are required in delivering water to coastal and southern portions of the state.

Most irrigation users within the State Water Project are in the San Joaquin Valley service area, where the 2006 estimated unit cost of water is USD60 per $1,000 \mathrm{~m}^{3}$. Irrigators would also be required to pay the operation, maintenance, and capital replacement costs of their local water agencies. Hence, most irrigators using water from the State Water Project must pay more than USD73 per $1,000 \mathrm{~m}^{3}$ for that portion of their water supply.

\subsection{Water Markets and Conjunctive Use}

Many farmers in western states have purchased irrigation water in market transactions in recent years, due to reductions in their annual water allocations from state and federal water purveyors. Farmers in some portions of California's San Joaquin Valley have seen their annual water supplies reduced by more than $50 \%$ in some years. When possible, some have purchased water from other farmers at prices that reflect prevailing supply and demand conditions. 
California's Department of Water Resources established and managed an Emergency Drought Water Bank in 1991 to facilitate the transfer of water from willing sellers to willing buyers. Prices in the Water Bank ranged from USD41 to USD142 per $1,000 \mathrm{~m}^{3}$, and most of the water was purchased by urban water supply agencies. Agricultural agencies accounted for about $21 \%$ of the sales from the Water Bank, primarily for farmers needing to finish irrigating seasonal crops or to preserve permanent crop plantings, such as tree fruits, nuts, and vines (Teerink, 1993b; Green and Hamilton, 2000). In sum, the Water Bank purchased 1,105,000 $\mathrm{m}^{3}$ of water at an average price of USD100 per $1,000 \mathrm{~m}^{3}$, and sold $488,000 \mathrm{~m}^{3}$ of water at an average price of USD140 per 1,000 $\mathrm{m}^{3}$. Carriage losses accounted for $150,000 \mathrm{~m}^{3}$ of water, while $375,000 \mathrm{~m}^{3}$ were carried over to the following year (Howitt, 1994).

The cost of pumping groundwater also provides information regarding incremental values, particularly in regions where farmers irrigate with both surface water and groundwater. The Arvin-Edison Water Storage District in Kern County, California was formed in 1942 for the purpose of obtaining irrigation water supplies from the Central Valley Project and reducing groundwater overdraft in the region (Schuck and Green, 2003a). The District recharges the aquifer in years when its surface water supply exceeds demand, and withdraws from the aquifer in years when demand exceeds supply. Farmers have adapted to the conjunctive concept by investing in wells to supplement their surface water deliveries. Reliable irrigation is essential in the District, given that about two-thirds of the 36,423 hectares cultivated each year are planted in fruits and vegetables (Schuck and Green, 2003b).

Table 8.

Estimated State Water Project Annual Entitlements and Unit Water Charges for 2006, by Service Area

\begin{tabular}{|c|c|c|c|}
\hline Service Area & $\begin{array}{c}\text { Annual } \\
\text { Entitlement }\end{array}$ & $\begin{array}{l}\text { Cost } \\
\text { Category }\end{array}$ & $\begin{array}{l}2006 \text { Estimated } \\
\text { Unit Cost }\end{array}$ \\
\hline & $\left(1,000 \mathrm{~m}^{3}\right)$ & & $\left(\$ / 1,000 \mathrm{~m}^{3}\right)$ \\
\hline Feather River & 49,113 & Capital, O, M \& R & 29 \\
\hline \multirow[t]{3}{*}{ North Bay } & 82,678 & Capital, O, M \& R & 186 \\
\hline & & Power & 27 \\
\hline & & Sum & 213 \\
\hline \multirow[t]{3}{*}{ South Bay } & 231,992 & Capital, O, M \& R & 70 \\
\hline & & Power & 35 \\
\hline & & Sum & 105 \\
\hline \multirow[t]{3}{*}{ Coastal } & 86,980 & Capital, O, M \& R & 382 \\
\hline & & Power & 96 \\
\hline & & Sum & 478 \\
\hline \multirow[t]{3}{*}{ San Joaquin Valley } & $1,672,070$ & Capital, O, M \& R & 44 \\
\hline & & Power & 16 \\
\hline & & Sum & 60 \\
\hline \multirow[t]{3}{*}{ Southern California } & $3,081,915$ & Capital, O, M \& R & 106 \\
\hline & & Power & 109 \\
\hline & & Sum & 216 \\
\hline Sum & $5,204,748$ & & \\
\hline \multicolumn{4}{|c|}{$\begin{array}{l}\text { Note: O, M \& R is Operations, Maintenance, and Replacement. } \\
\text { Sources: Teerink, 1993b; California, } 2006 .\end{array}$} \\
\hline
\end{tabular}

The District must raise the unit price of surface water in years of short supply, to cover its costs of operating and maintaining the irrigation system. As the price of surface water increases, farmers tend to pump more groundwater. Schuck and Green (2003a) find that when the price of surface water reaches $62 \%$ of the marginal cost of pumping groundwater, the likelihood of a farmer having a well reaches $50 \%$. Surface water prices in Arvin-Edison ranged from USD41 to USD71 per $1,000 \mathrm{~m}^{3}$ in 1997 , while the estimated cost of pumping 
groundwater ranged from USD51 to USD91 per $1,000 \mathrm{~m}^{3}$ (Schuck and Green, 2003a). These prices are notably higher than those observed in some other districts in California with more senior water rights or exchange contracts with the Bureau of Reclamation. Yet they are typical of the incremental cost of irrigation water in regions where farmers must pump groundwater from substantial depths, purchase water in market transactions, or obtain surface water from the State Water Project.

\subsection{Irrigation in Arizona}

Groundwater has long been an important source of irrigation water in Arizona, an arid state in the American southwest. Demand for water has increased substantially over time, with increasing development of major cities including Phoenix and Tucson. The federally funded Central Arizona Project was constructed in part to relieve pressure on aquifers serving those cities by delivering surface water from the Colorado River. In conjunction with development of the Central Arizona Project, the state passed a Groundwater Management Act in 1980 that requires urban areas to achieve "safe-yield" management of aquifers by 2025 (Bolin et al., 2008). The Act allows farmers to sell irrigation rights with the sale of farmland, enabling water to move from agricultural to nonagricultural uses (Collins and Bolin, 2007).

The Groundwater Management Act established active management areas in which the state requires farmers to measure and report water use with flow meters on all wells and irrigation turnouts (Needham and Wilson, 2005). The state regulates the volume of water farmers may withdraw each year, while allowing farmers to earn credit for portions of their allotments that are not used. The notion of water allotments has been helpful in gaining awareness of water scarcity in Arizona, but many farmers have accumulated large credits for withdrawals that enable them to use substantial amounts of water in some years (Needham and Wilson, 2005). Farmers also may sell credits to other farmers.

The Maricopa-Stanfield Irrigation and Drainage District (MSIDD) in central Arizona is typical of large, farmer organized and managed irrigation districts in the American southwest. The 35,000-ha district was formed in 1962 for the purpose of enabling farmers to receive surface water irrigation deliveries from the federal Central Arizona Project. The district blends CAP water with groundwater developed from district-operated wells, for delivery to farm-level turnouts on each 240-ha parcel (Wilson and Gibson, 2000). Groundwater withdrawals and all deliveries to farm turnouts are measured with volumetric meters. The district manages $360 \mathrm{~km}$ of canals and delivers water to 50 customers.

The economics of irrigated farming have been challenging since the MSIDD was formed, as described in a diagnostic analysis performed in the early 1990s (Dedrick et al., 2000). The challenge arose in part because MSIDD assumed a substantial debt repayment obligation in constructing the water distribution system from the main CAP canal and within the district (Wilson and Gibson, 2000). The cost of debt service was assessed upon each farmer holding a water right, at the annual rate of USD210 per hectare. Many farmers received annual purchase or lease payments from MSIDD for their irrigation wells, thus offsetting a portion of the cost of debt service. The well payments ranged from USD49 to USD170 per hectare, with an average payment of USD99 per hectare (Wilson and Gibson, 2000).

The MSIDD recovers its non-water variable costs through a volumetric water charge. In the early 1990 s the charge was USD16 per $1,000 \mathrm{~m}^{3}$ (Wilson and Gibson, 2000). The average water costs during the period declined from USD54 per $1,000 \mathrm{~m}^{3}$ for summer water and USD34 per $1,000 \mathrm{~m}^{3}$ for winter water in 1990 to USD40 per $1,000 \mathrm{~m}^{3}$ for summer water and USD27 per $1,000 \mathrm{~m}^{3}$ for winter water in 1994 (Dedrick et al., 2000). The district lowered its water prices over time to encourage greater production of winter grains and to spread its non-variable water costs over a larger volume of water delivered.

The price of water sold by the CAP to agricultural contractors, such as the MSIDD, has increased over time with increases in the costs of operation, maintenance, and pumping. The CAP water rates for long-term agricultural subcontracts for 2008 through 2010 and the advisory rates for 2011 through 2014 are shown in Table 9. The current price of USD75 per $1,000 \mathrm{~m}^{3}$ will increase to USD97 per $1,000 \mathrm{~m}^{3}$ in 2010 . The price is projected to be USD121 per $1,000 \mathrm{~m}^{3}$ in 2014 . The capital charge of USD2 per 1,000 $\mathrm{m}^{3}$ will not be imposed beyond 2011 (CAP, 2008). 
Table 9.

Central Arizona Project Expected Water Rates, 2008 through 2014

\begin{tabular}{|c|c|c|c|c|c|c|c|}
\hline Cost Component & 2008 & 2009 & 2010 & 2011 & 2012 & 2013 & 2014 \\
\hline & \multicolumn{7}{|c|}{ (Dollars per $1,000 \mathrm{~m}^{3}$ ) } \\
\hline \multicolumn{8}{|l|}{ Fixed Operations, } \\
\hline Maintenance, and Repair & 45 & 51 & 56 & 62 & 67 & 71 & 74 \\
\hline Pumping Energy & 29 & 36 & 40 & 41 & 43 & 45 & 47 \\
\hline Capital Repayment & 2 & 2 & 2 & 2 & & & \\
\hline Total Charge & 75 & 89 & 97 & 105 & 110 & 117 & 121 \\
\hline $\begin{array}{l}\text { Source: Central Arizona Pro } \\
\text { http://www.cap-az.com/stat }\end{array}$ & $\begin{array}{l}\text { ct Fina } \\
\text { index.c }\end{array}$ & $009 / 20$ & $\begin{array}{l}0 \text { Rate } \\
\text { t } I D=30\end{array}$ & chedul & availabl & at: & \\
\hline
\end{tabular}

\subsection{Irrigating with Groundwater on the High Plains}

The Ogallala Aquifer lies beneath portions of eight states in the American west, including Texas, New Mexico, Kansas, Oklahoma, Colorado, Nebraska, Wyoming and South Dakota. The Ogallala has been the source of substantial, large-scale irrigation development, beginning in the 1950s, when affordable technology became available for extracting groundwater and applying it to large fields of cotton, corn, winter wheat, and sorghum (Warren et al., 1982; Peterson et al., 2003). The number of wells on the Texas High Plains increased from 48,000 in 1958 to 101,000 in 2000, as farmers increased their production of irrigated crops (Colaizzi et al., in press). The Ogallala is largely a fossil aquifer with a very slow rate of natural recharge. By 1977, groundwater levels were declining by at least $15 \mathrm{~cm}$ per year in $82 \%$ of the area irrigated with groundwater in Texas (Sloggett and Mapp, 1984). Severe overdraft was observed also in Kansas, Oklahoma, and New Mexico. The cumulative decline in groundwater levels has exceeded 30 meters in some areas of Texas and Oklahoma (Norwood and Dumler, 2002).

The economy of the region depends largely on crop and livestock production and processing, yet the rate of withdrawal from the Ogallala greatly exceeds the rate of recharge (Seo et al., 2008). The unsustainable use of water from the Ogallala has attracted substantial attention from state and federal agencies in recent years. Most states have passed laws that enable the formation of groundwater management districts, controlled by local irrigators, to implement programs for optimizing the long-term use of water from the aquifer. In Kansas, New Mexico, and Colorado, farmers must apply for permits from groundwater management districts to drill new wells (Peterson et al., 2003). Permits are not issued if new wells will impact water availability for nearby farmers. Farmers in Kansas are required also to measure the volume of groundwater they use each year and to provide that information to the local management district.

Farmers on the High Plains region of Texas can withdraw and utilize groundwater without regulation, as the Texas Supreme Court has ruled that a landowner is the "absolute owner of the soil and percolating water (Peterson et al., 2003)". Irrigation expanded rapidly in the region during the 1960s and the early 1970s. Irrigated area increased from 1.83 million hectares in 1958 to 2.42 million hectares in 1974, before entering a period of decline, driven largely by the increases in energy costs and the diminishing productivity of irrigation wells (Colaizzi et al., 2008). Irrigated area reached a low point of 1.59 million hectares in 1989, before recovering to 1.87 million hectares in 2000, about the same area that was irrigated in 1958. As the irrigated area has changed over time, so too have farm-level choices regarding irrigation technology. Gravity-flow surface irrigation methods have largely been replaced by center-pivot and low-pressure sprinkler systems and subsurface drip irrigation (Colaizzi et al., 2008).

Lacking administrative authority to limit pumping in Texas, several agencies have worked with irrigators to encourage improvements in water management that will reduce the aggregate rate of groundwater withdrawals. Declining groundwater levels and rising prices of natural gas also have motivated to farmers to improve irrigation management. The estimated cost of pumping water from the Ogallala increased from USD0.08 per mm to more than USD0.20 mm in some areas (Norwood and Dumler, 2002). The current estimated investment cost for an irrigation system in the region is USD741 per hectare and the estimated variable cost of pumping water (from a 
depth of 61 meters) and operating the system is USD772 per hectare (Seo et al., 2008). In a sense, the increasing costs of two scarce resources (water and natural gas) are motivating necessary adjustments in water use. Guerrero et al., (2006) report that in any given year, higher natural gas prices can cause up to an $18 \%$ reduction in the volume of water pumped for irrigation in the region. Part of the reduction is due to changes in crop choices $(2.3 \%)$, and leaving land fallow (4.1\%), while part is due also to smaller applications of irrigation water (11.4\%).

\subsection{Irrigation in Georgia, an Eastern State}

Groundwater is the source of about two-thirds of the irrigation water used by farmers in the southeastern state of Georgia, where the amount of water used for irrigation increased from about 67 million $\mathrm{m}^{3}$ in 1950 to 798 million $\mathrm{m}^{3}$ in 1980 and 1,505 million $\mathrm{m}^{3}$ in 2000 (Fanning, 2003). Much of the increase has been motivated by increasing demand for agricultural products in Georgia and by the increasing use of center pivot irrigation systems, beginning in the late 1970s.

State law in Georgia enables farmers to use water as they choose, provided they have access to groundwater or diversions from surface water sources. Using farm-level irrigation and crop production data collected during 1999 through 2002, Gonzalez-Alvarez et al. (2006) estimate farmer responsiveness to changes in the marginal cost of pumping groundwater. The estimated price elasticity at the mean value of observed variables is -0.27 , which is consistent with the results of many other authors who describe inelastic responsiveness to changes in irrigation water prices. Gonzalez-Alvarez et al. (2006) suggest that a USD0.81 per 1,000 $\mathrm{m}^{3}$ increase in pumping cost from its mean value, holding other variables at their mean values, would reduce water use by about $12 \mathrm{~m}^{3}$ per hectare. Hence, an increase of USD41 per $1,000 \mathrm{~m}^{3}$, perhaps to represent scarcity value, would reduce water use by about $610 \mathrm{~m}^{3}$ per hectare. The authors suggest further that actual responsiveness to the imposition of water pricing might be greater than they have estimated, as a change in the institutional structure of water supply might generate greater awareness among farmers of the need for improvements in water management.

While the state of Georgia does not charge farmers for irrigation water, it does issue permits that allow farmers to irrigate. A voluntary permit program became mandatory in 1988, and by 2001 more than 21,000 irrigation permits had been issued to about 8,700 farmers or farm companies (Mullen et al., 2005). Farmers must obtain an irrigation permit for each field they will irrigate using either surface water or groundwater. Hence, the number of permits is substantially larger than the number irrigated farms in Georgia. When applying for permits, farmers must specify the crops to be grown and the irrigation methods they will use, such as center pivot sprinklers, solid set sprinklers, or drip irrigation.

Georgia placed a moratorium on agricultural irrigation permits in the Flint River Basin in 1999, thus creating a scarcity condition in which new permits were not available (Elfner and McDowell, 2004; Petrie and Taylor, 2007). The market value of an irrigation permit can be deduced by examining differences in the sale prices of land with and without irrigation permits. Petrie and Taylor (2007) examined land sales in Georgia before and after the moratorium was imposed. Prior to imposing the moratorium, there was no significant difference in the sale price of farmland with or without an irrigation permit. After imposition, farmland with an irrigation permit sold for about USD1,236 per hectare more than farmland without a permit.

Historical data suggest that farmers expect to use about $2,134 \mathrm{~m}^{3}$ of water per hectare each year (Petrie and Taylor, 2007). Hence, the USD1,236 per hectare land sale price differential is equivalent to an annual value of USD2 8 per $1,000 \mathrm{~m}^{3}$ of water, assuming an interest rate of $3 \%$ and a 30 -year time horizon (Petrie and Taylor, 2007). That value is consistent with other estimates of the average value of irrigation water in other regions.

In April 2000, Georgia implemented the Flint River Drought Protection Act, which requires the state to conduct an auction in drought years to encourage some farmers to suspend irrigation (Cummings et al., 2004). In such years, the state first determines the area it must remove from irrigation to maintain adequate water supplies for other purposes, and then accepts bids from farmers willing to suspend irrigation in exchange for compensation. The auction mechanism provides information regarding the incremental value of irrigation to farmers in the Flint River Basin. 
In an irrigation reduction auction conducted prior to the 2001 irrigation season, $85 \%$ of the offers made by 197 farmers were within the range of USD247 to USD1,236 per hectare. After several rounds of bidding, in which the maximum accepted bids ranged from USD309 to USD494 per hectare, the state obtained the permits for irrigation on 13,357 hectares at a total cost of almost USD4.5 million, or an average price of about USD337 per hectare (Cummings et al., 2004). Farmers "leasing" their irrigation permits to the state could produce rainfed crops or leave their land idle for the season. Assuming an average irrigation diversion of $7,623 \mathrm{~m}^{3}$ per hectare, the USD337 per hectare average price reflects an incremental value of irrigation of about USD44 per 1,000 $\mathrm{m}^{3}$.

\section{Policy Conclusions}

Through much of the 20th century, many farmers in the western United States enjoyed affordable prices for irrigation water, due partly to federal policies that encouraged the settlement and development of arid lands along the frontier of the country's westward expansion. The Reclamation Act of 1902, which created the U.S. Bureau of Reclamation for the purpose of promoting irrigation in the 17 western states, contained generous provisions that allowed farmers to repay only the capital cost of construction, with no interest charges. Revisions of the Act extended the repayment periods and provided additional exemptions from some of the repayment obligations. By the 1960s and 1970s, public concern had arisen regarding the size of the interest-rate subsidies provided to irrigated agriculture, particularly in the western states.

The Reclamation Reform Acts of 1982 and 1992 contained provisions that notably increased the farm-level cost of irrigation water and, in some cases, reduced irrigation supplies. The1992 Act, in particular, reflected changing public preferences regarding the allocation of water between competing uses, including the environment. A substantial portion of the agricultural water supply in California's Central Valley was re-allocated to the environment and farmers were assessed new fees to pay for environmental restoration. Many farmers have been required also to repay operation and maintenance deficits that accumulated over time, thus further increasing the farm-level cost of irrigation water.

At the same time that federal subsidies for irrigation water have been declining, state and local water agencies have been requiring farmers to pay larger portions of the full cost of developing irrigation supplies. The California State Water Project provides a helpful example. Most contractors, including irrigation districts, are required to pay the full supply-cost of water that reflects both the investment cost and the annual costs of operation and maintenance. Interest is assessed and farmers must pay for the annual fixed costs, even in years when the actual water deliveries are reduced substantially by drought conditions. Agricultural water supply accounts for less than one-third of State Water Project deliveries, largely because the average per-unit cost of water exceeds the farmlevel willingness to pay for irrigation water.

Irrigation costs have been increasing also in regions where farmers rely on limited supplies of groundwater, such as the High Plains of Texas and other states served by the fossil Ogallala Aquifer. Increases in the price of natural gas and declining water levels in the aquifer have motivated farmers to improve their irrigation practices and increase the values they generate per unit of water extracted. Several states have established groundwater management districts and limit the development of new wells, in an effort to slow the rate of depletion in a largely agricultural region that depends on irrigation. Some states also require farmers to measure and report the volume of water they withdraw from the aquifer each year, thus generating helpful data for state agencies, while also increasing farm-level awareness of the rate of aquifer depletion in the region.

Many farmers in western states participate actively in water markets to obtain a portion of their irrigation supply or to sell or lease water in years when they can gain financially from such transactions. Several states and the federal government have embraced the concept of water marketing, and public agencies have implemented services to facilitate water sales and leases in recent years. In theory the market price of water reflects current supply and demand conditions, thus motivating farmers and other water users to consider the opportunity cost of water when choosing how much to purchase and apply. In some years farmers purchase water in the market to complete an irrigation season or to ensure sufficient water supply for their perennial crops. The incremental price can be substantially higher than the average price paid for the larger portion of their annual water allocation.

Farmers in eastern and midwestern states also are facing higher costs of irrigation water, as competition increases for limited supplies and the prices of energy required to pump groundwater, lift water from rivers, and pressurize sprinkler systems increases. Water rights and legislation are not as well developed in the humid East and Midwest as they are in the arid western states. Yet increasing demands and the potential for changing weather 
patterns are motivating several states to develop water policies and laws. The experience gained during many years in the arid west should be very helpful to such states as they consider the potential roles of well-defined property rights, prices, and markets in motivating wise use and efficient allocations among irrigators and other water users.

In summary, the policy gradient with regard to irrigation water pricing in the United States is positive from both economic and public welfare perspectives. There are still many farmers in some areas who benefit from policies that allow them to forego repaying capital expenditures or to schedule repayment over many years with zero interest. But the number and proportion of such arrangements has declined in recent years with revisions of federal legislation designed to improve water use efficiency on farms and throughout arid regions. Both the United States Congress and state governments seem inclined to require full supply-cost recovery for any future irrigation projects and to improve the rate of cost recovery, as much as possible, from existing projects. There remain notable gaps in repayment on several historical projects, particularly in areas where farmers have very senior water rights or they formed long-term exchange agreements for their riparian rights, but the relative importance of those cases likely will continue to decline.

The costs of pumping groundwater will continue to increase with rising energy costs and with declining water levels. State governments likely will increase their efforts to manage groundwater as scarcity increases in many areas, and as the public becomes more concerned about the regional economic implications of groundwater overdraft. Recent increases in public awareness of the potential implications of climate change and public concerns regarding sustainability likely will encourage public officials to intensify their management of groundwater resources, while also enhancing the likelihood that farmers will accept new regulatory measures that might include charges that reflect scarcity values.

In the United States, as elsewhere, the days of very low cost irrigation water, whether delivered from a publicly supported large-scale system, pumped from an aquifer, or diverted from a nearby river likely are diminishing at a non-trivial rate. Rising energy costs, changes in public preferences, and increasing public awareness are contributing to this trend. Policy makers will increasingly rely on irrigation pricing strategies and markets to motivate improvements in water management and to improve resource allocation. Farm-level costs will increase, but innovative management and wise use of technology will enable farmers to adjust in ways that generate greater value from limited water resources.

96. Looking forward, farmers in the United States and elsewhere must adjust to rising energy costs and increasing water scarcity. While the outlook for agricultural prices is uncertain, recent increases in food prices suggest that crop prices might be notably higher in some years. Higher crop prices will contribute to higher land prices, just as subsidies for irrigation water have done historically. From a water management perspective, higher land prices are helpful in promoting farm-level crop and technology decisions that generate higher values per unit of irrigation water. Thus the impacts of irrigation subsidies that once encouraged farmers to plant low-valued crops and to minimize water management efforts, likely will be negated in future by rising land prices and increasing water scarcity. 


\section{References}

Bolin, B., Collins, T., Darby, K., 2008. Fate of the verde: Water, environmental conflict, and the politics of scale in Arizona's central highlands. Geoforum 39(3): 1494-1511.

Burt, C.M., 2007. Volumetric irrigation water pricing considerations. Irrigation and Drainage Systems 21(2): 133-144.

California Department of Water Resources, 2006. Management of the California State Water Project. Bulletin 132-05. Sacramento, California, 367 pages.

Carruthers, I., Rosegrant, M.W., Seckler, D., 1997. Irrigation and food security in the 21 st century. Irrigation and Drainage Systems 11(2): 83-101.

Central Arizona Project (CAP), 2008. Final 2009/2010 Rate Schedule, available at: http://www.capaz.com/static/index.cfm?contentID=30, accessed Sept.27.2008.

Colaizzi, P.S., Gowda, P.H., Marek, T.H., Porter, D.O., in press. Irrigation in the Texas High Plains: A brief history and potential reductions in demand. Irrigation and Drainage, forthcoming.

Collins, T.W., Bolin, B., 2007. Characterizing vulnerability to water scarcity: The case of a groundwaterdependent, rapidly urbanizing region. Environmental Hazards 7(4): 399-418.

Cummings, R.G., Holt, C.A., Laury, S.K., 2004. Using laboratory experiments for policymaking: An example from the Georgia irrigation reduction auction. Journal of Policy Analysis and Management 23(2): 341-363.

Dedrick, A.R., Bautista, E., Clyma, W., Levine, D.B., Rish, S.A., 2000. The Management Improvement Program (MIP): A process for improving the performance of irrigated agriculture. Irrigation and Drainage Systems 14(1-2): 5-39.

Elfner, M.A., McDowell, R.J., 2004. Water conservation in Georgia: Bringing efficiency into mainstream thinking. Journal of the American Water Works Association 96(4): 136-142.

Fanning, J.L., 2003. Water use in Georgia, 2000; and trends, 1950-2000. In: K.J. Hatcher (Ed.) Proceedings of the 2003 Georgia Water Resources Conference, Univ. of Georgia, April 23-24.

Fischhendler, I., Zilberman, D., 2005. Packaging policies to reform the water sector: The case of the Central Valley Project Improvement Act. Water Resources Research 41(7): 1-14.

General Accounting Office (GAO), 1985. Bureau of Reclamation's Central Utah and Central Valley Projects Repayment Arrangements. United States General Accounting Office, GAO/RCED-85-158, Washington, D.C., 34 pages.

General Accounting Office (GAO), 1991. Reclamation Law: Changes needed before water service contracts are renewed. United States General Accounting Office, GAO/RCED-91-175, Washington, D.C., 32 pages.

General Accounting Office (GAO), 1994. Water Subsidies: Impact of higher irrigation rates on Central Valley Project farmers. United States General Accounting Office, GAO/RCED-94-8, Washington, D.C., 92 pages.

General Accounting Office (GAO), 1996. Bureau of Reclamation: Information on allocation and repayment of costs of constructing water projects. United States General Accounting Office, GAO/RCED-96-109, Washington, D.C., 80 pages.

Guerrero, B., Amosson, S., Marek, T., Almas, L., 2006. Natural gas price impact on irrigated agricultural water demands in the Texas Panhandle region. The Texas Journal of Agriculture and Natural Resources 19: 102112. 
Gollehon, N., Quinby, W., 2000. Irrigation in the American West: Water and economic activity. International Journal of Water Resources Development 16(2): 187-195.

Gollehon, N., Quinby, W., 2006. Irrigation resources and water costs. In: Agricultural Resources and Environmental Indicators, 2006 Edition, EIB-16, Economic Research Service, USDA, Washington, D.C., pages 24-32.

Green, G.P., Hamilton, J.P, 2000. Water allocation, transfers and conservation: Links between policy and hydrology. International Journal of Water Resources Development 16(2): 197-208.

Gonzalez-Alvarez, Y., Keller, A.G., Mullen, J.D., 2006. Farm-level irrigation and the marginal cost of water use: Evidence from Georgia. Journal of Environmental Management 80(4): 311-317.

Howell, T.A., 2001. Enhancing water use efficiency in irrigated agriculture. Agronomy Journal 93(2): 281-289.

Howitt, R.E., 1994. Empirical analysis of water market institutions: The 1991 California water market. Resource and Energy Economics 16(4): 357-371.

Loomis, J., 1999. Water transfer and major environmental provisions of the Central Valley Project Improvement Act: A preliminary economic evaluation. Water Resources Research 30(6): 1865-1871.

Merrett, S., 2002. Water for Agriculture: Irrigation Economics in International Perspective. Spon Press, London.

Molle, F., Berkoff, J., 2008. Water pricing in irrigation: Mapping the debate in the light of experience. In: Molle, F., Berkoff, J., Irrigation Water Pricing: The Gap Between Theory and Practice. CAB International, Oxfordshire, U.K.

Moore, M.R., 1999. Estimating irrigators' ability to pay for reclamation water. Land Economics 75(4): 562-578.

Mullen, J.D., Escalante, C., Hoogenboom, G., Yu, Y., 2005. Determinants of irrigation farmers' crop choice and acreage allocation decisions: Opportunities for extension service delivery. Journal of Extension 43(5): Article 5RIB3.

Needham, R., Wilson, P.N., 2005. Water conservation policy in Arizona agriculture: Assessing the Groundwater Management Act of 1980. Arizona Review 3(1): 13-16.

Norwood, C.A., Dumler, T.J., 2002. Transition to dryland agriculture: Limited irrigated vs. dryland corn. Agronomy Journal 94(2): 310-320.

Peterson, J.M., Marsh, T.L., Williams, J.R., 2003. Conserving the Ogallala Aquifer: Efficiency, equity, and moral motives. Choices, First Quarter 2003: 15-18.

Petrie, R.A., Taylor, L.O., 2007. Estimating the value of water use permits: A hedonic approach applied to farmland in the southeastern United States. Land Economics 83(3): 302-318.

Rezendes, V.S., 1997. Bureau of Reclamation: Reclamation law and the allocation of construction costs for federal water projects. Testimony before the Subcommittee on Water and Power Resources, Committee on Resources, House of Representatives, General Accounting Office, GAO/T-RCED-97-150, Washington, D.C., 8 pages.

Schuck, E., Green, G.P., 2003a. Conserving one water source at the expense of another: The role of surface water price in adoption of wells in a conjunctive use system. International Journal of Water Resources Development 19(1): 55-66.

Schuck, E., Green, G.P., 2003b. Supply-based water pricing in a conjunctive use system: Implications for resource and energy use. Resource and Energy Economics 24(3): 175-192.

Sloggett, G.R., Mapp, H.P., 1984. An analysis of rising irrigation costs in the Great Plains. Water Resources Bulletin 20(2): 229-233.

Teerink, J.R., 1993a. Water allocation methods and water rights in the western states, U.S.A. In: Teerink, J.R., Nakashima, M., (Eds.) Water Allocation, Rights, and Pricing: Examples from Japan and the United States. World Bank Technical Paper Number 198. The World Bank, Washington, D.C., 68 pages.

Teerink, J.R., 1993b. Water supply pricing in California. In: Teerink, J.R., Nakashima, M., (Eds.) Water Allocation, Rights, and Pricing: Examples from Japan and the United States. World Bank Technical Paper Number 198. The World Bank, Washington, D.C., 68 pages. 
United States Department of Agriculture (USDA), 2002. Agricultural Resources and Environmental Indicators, Economic Research Service, Washington, D.C.

United States Department of Agriculture (USDA), 2006. Agricultural Resources and Environmental Indicators, Economic Research Service, Washington, D.C.

Weinberg, M., 1997. Federal water policy reform: Implications for irrigated farms in California. Contemporary Economic Policy 15(2): 63 to73.

Westlands Water District (WWD), 2008. Westlands Water District 2008-09 Water Rates and Charges, available at: wwd.westlandswater.org, accessed in September 2008.

Warren, J., Mapp, H., Ray, D., Kletke, D., Wang, C., 1982. Economics of declining water supplies in the Ogallala Aquifer. Ground Water 20(1): 73-79.

Wilkins-Wells, J., Lagae, H.J., Anderson, R.L., Anwer, M.S., 1999. Operational costs of canal companies and irrigation districts in the Intermountain Region. Presented at the Western Agricultural Economics Association Annual Meeting, Fargo, North Dakota, 13 pages.

Wilson, P.N., Gibson, R.D., 2000. The economics of agriculture in the Maricopa-Stanfield Irrigation and Drainage District in Central Arizona. Irrigation and Drainage Systems 14(1-2): 121-138. 